\title{
Interlocking Newspaper and Telephone Company Directorates in Southeastern Iowa, 1900-1917
}

\section{Roy Alden Atwood}

Newspapers and telephone systems have occupied common ground as far back as the establishment of the telephone industry when, in non-Bell territories particularly, publishers and editors were some of the principal developers and directors of independent telephone operations. These close relationships were evident in southeastern lowa between 1900 and 1917. Editors, publishers, and owners of local newspapers often possessed decision-making powers in their local telephone companies, had significant financial commitments to them, and used one medium to promote the other. The bond between newspaper and telephone company directorates was a firm one.

When the initial set of Bell Telephone Company patents expired in the early 1890s, the largest concentration of independent telephone systems began to shift from the eastern seaboard to the Midwest. The federal population censuses of 1880 and 1890 along with censuses of the electrical industries taken every fifth year beginning in 1902 indicate that the period of the most

Research for this project was made possible in part through a grant from the Iowa Center for Communication Study, School of Journalism and Mass Communication, the University of Iowa. A preliminary version of this paper was presented at the West Coast Journalism History Conference in San Francisco, February 1982. I am grateful to Professor Ted C. Smythe, California State University-Fullerton, for his helpful comments on the earlier draft. 
dramatic phone system growth nationally, and for the Midwest particularly, was between 1890 and 1917 . The number of phone systems in 1902 was about seventy-five times greater than the number in existence in 1890.

During this period Iowa began to emerge as a national leader in the independent telephone business. By 1917 Iowa led the nation in total number of telephone companies although the state had barely two million residents and only six cities with populations greater than fifteen thousand. In 1917 Iowa had 5,223 telephone companies in operation and over 86 percent of the rural households in the state had at least one telephoneagain a national high. ${ }^{1}$

Several factors contributed to the rapid growth of the rural phone industry. First, after the expiration of the Bell patents, independent phone equipment manufacturers sprang up all over the nation, with the largest companies concentrated around Chicago. The ensuing competition in the phone hardware business resulted in the greater availability of telephone equipment and drove down the costs for setting up a system, making possible for the first time wide-scale rural phone development. ${ }^{2}$

The so-called problem of isolated farm life was a second factor contributing to the growth of Iowa's rural phone industry. Often cited in local newspapers and telephone trade journals as a major problem relieved by the phone, farm isolation was offered as a rationalization for the construction of rural systems. ${ }^{3}$ Supporting this rationalization was the realization that after 1880 , at the very time the phone was entering the con1920).

1. Census of Electrical Industries, 1917: Telephones (Washington, D. C.,

2. See any advertisers' index published in the trade journal Telephony between 1900 and 1917. Phone hardware was also available through the mail order catalogs of companies such as Sears, Montgomery Ward, and others. Interestingly, since the deregulation of the telephone industry recently, phones are now back in the mail order catalogs and retail market.

3. The newspapers listed below abounded with articles extolling the virtues of the telephone for relieving isolation. The July 1904 issue of Telephony also reported that farm isolation was a "chief source of dissatisfaction among farmers' families" (34-35). The federal government's Country Life Commission came to the same conclusion in its final report. (Report of the Commission on Country Life, 60th Cong., S.Rpt. 705, 128.)

The following newspapers provided data for this study. The dates in parentheses indicate the spans of years examined. Washington County: Ains- 
sumer market, Iowa's population began a significant decline. Between 1900 and 1910 the 0.3 percent loss in state population seemed slight, but lowa was the only state in the union to lose population in that decade. It was primarily the rural districts that suffered the greatest population loss. ${ }^{4}$ For many the telephone held the promise of at least some measure of relief from the social isolation in the Corn Belt.

Third, rural free mail delivery, hailed as the "common people's luxury" when it came to Iowa around 1900, did bring farm families some relief from their isolated existence. But whatever news and color of the outside world the rural delivery system may have brought to the farmhouse gate, it rendered obsolete the small local post offices where people had gathered to share news and gossip and to discuss events of the day. Rural free delivery embodied a profound and fundamental shift in the character of public life and public discourse that interfaced with the advent of the telephone in rural lowa backwashes. ${ }^{5}$

Finally, the telegraph served as an important forerunner to the telephone industry in lowa. Almost without exception, the telephone was introduced in areas that already had railway and telegraph connections. The transition between the telegraph and the telephone seemed natural. The idea of the telephone involved no quantum leap of the imagination from the telegraph; it was perceived as an extension of the electrical principles involved with telegraphy. Legally, telephone companies were

worth Clipper (1915-1917), Crawfordsville Imprint (1912-1917), Washington Evening-Journal (1900-1903, 1916), Washington Press (1900-1906), Washington County Press (1907-1917), Wellman Advance (1900-1915); Iowa County: Marengo Democrat (1905-1906), Marengo Republican (1903-1904), North English Record (1909-1917), lowa County Advertiser (1902-1905, 1907-1910, 1912-1914), Victor Index (1906), Williamsburg Journal-Tribune (1909); Johnson County: Hills Echo (1905-1906), lowa Post (German, 1900-1901), Johnson County Independent (1912-1916), Iowa City Daily News (1906-1907), lowa City Citizen (1900-1917), Daily lowa State Press (1900-1904, 1909).

4. Bureau of the Census. 13th Census of the United States, 1910, (Washington, D. C., 1923).

5. The March 14, 1901 issue of the Wellman Advance voiced concern over the demise of the rural post office: Lexington people have taken a wise step in petitioning the government not to interfere with the post office at Lexington, in case rural mail routes are established in that section. . . . A good thing for a part of the people should not be secured by doing an injustice to the rest of the people. Get all the rurals possible, but spare the country post office." 
classified with telegraph companies for the purpose of determining the jurisdiction of justices of peace over them, for deciding where and how they and their property would be assessed, and for controlling access to rights of way on public and municipal properties. ${ }^{6}$

Similarly, the United States Bureau of the Census maintained that, in a general sense, the definition of "telephone" was embraced in that given for "telegraph." As late as 1912, the bureau published its telephone industry studies with those of the telegraph industry, municipal fire alarms, and police patrol signaling systems under a single cover. ${ }^{7}$ This conceptual link between the telephone and other electrical devices had further justification: most of the early telephone lines in the state were old telegraph lines.

The pattern of telephone system growth, however, did not follow that of the telegraph nor did phone lines simply radiate out from town centers to outlying rural districts. Instead, even while the initial town systems were getting off the ground, small groups of farmers organized their own mutual companies and constructed their own lines. On an average, farmer or rural telephone companies had about ten to fifteen patrons. These small, mutually owned and operated lines made up the bulk of the Iowa phone business. In 1907 there were 129 commercial and predominantly urban phone companies compared to 3,316 mutual rural lines. By 1917, of the total 5,223 companies operating in the state, 5,071 were mutual lines. ${ }^{8}$

The rural telephone companies did not hook up immediately with other rural lines or with the more established and more sophisticated commercial town systems. Many of the smaller farmer lines remained strictly local party lines for as many as four years after their establishment. Eventually, the push for line consolidation came from two opposite directions: from the commercial company owners wishing to expand their

6. See Franklin v. N. W. Tel., 69 Iowa 97, 28 N. W. 461; Iowa Union Tel. Co. v. Board of Equalization, 67 lowa 250, 25 N. W. 155; Hockett v. State, 105 Ind. 250, 5 N.E. 178.

7. Bureau of the Census, Telephones and Telegraphs and Municipal Electric Fire Alarm and Police Patrol Signaling Systems, 1912 (Washington, 1915). Also see S. Walter Jones, A Treatise on the Law of Telegraph and Telephone Companies Including Electric Law, 2nd ed. (Kansas City, 1916), 4-5.

8. Census of Electrical Industries, 1917. 
business and from the farmers who wished to establish a mutual exchange that would link them to other farmer lines and nearby towns.

As early as 1907, the commercial companies were embarking on advertising campaigns designed to lure farmers and rural companies onto their systems. For farmers still without phones, the ads claimed that "the telephone [was] no longer a luxury, but a necessity." For the existing mutual farm lines, the ads appealed to the advantage of a town connection, of being linked to a central exchange, and of listings in the town directory. ${ }^{9}$

Those farmer systems that were within five to ten miles of a firmly established commercial city operation had little choice but to go with the commercial exchange. Those who lived near smaller commercial town exchanges, or near towns with no exchange at all, employed a different strategy. By getting together anywhere from ten to thirty farmer phone companies, farmers would appeal to the town lines to join them in establishing a mutual exchange on a strictly non-profit basis. These mutual exchanges would then purchase a switchboard and usually install it in a town office.

For both the commercial and mutual exchanges, the town business leaders exercised functional, if not outright, control over the systems. In most of the commercial systems, their control was complete. In mutual systems, their control was ensured by the very character of the exchange. Once an exchange was organized, it became a full-fledged business in its own right, requiring operators, technicians, bookkeepers, laborers, and managers. Farmers had neither the time nor the skills to handle all of these tasks. Consequently, the management and daily decision-making powers rested de facto with those closest to the operations and with those most skilled in business practices: the town merchants and managers.

Of the 1,521 persons identified as holding some position with one or more of the 251 telephone companies operating in Washington, Iowa, and Johnson counties between 1900 and 1917, 945 were identified in the 1915 lowa census. Of those

9. Washington County Press, 1 March 1907. See any of the Washington Telephone Company ads in the Washington Evening Joumal or the Washington County Press between 1907 and 1917. 
who appeared in the census, only three listed themselves as newspaper editors or publishers. Over the entire eighteen-year period studied, however, a total of eleven persons were identified as editors, publishers, or correspondents. ${ }^{10}$

Although their number was relatively small, the role of these eleven newspersons was nevertheless pivotal in the emergent local telephone businesses and in their communities. They were affiliated with southeastern Iowa's largest daily and weekly newspapers, and they directed the largest telephone systems in Iowa, Johnson, and Washington counties. They represented about one-third of the news operations in the three counties and controlled about one-third of the local newspaper circulation. ${ }^{11}$ Five persons in Washington County, five in Iowa County, and one in Johnson County directed both newspaper and telephone company operations.

The Washington Evening Journal, edited and published by Orville Elder from 1901 until his death in 1940, was the largest news operation and the only daily newspaper in Washington County. Elder also became the president of the Washington Telephone Company in 1907. When he assumed the presidency and became the principal stockholder, the company was worth over $\$ 60,000$ and had nearly one thousand telephones. Under Elder's editorship, the Evening Journal became the official county newspaper and doubled its circulation between 1901 and 1917at the same time that the county's population declined slightly. ${ }^{12}$

10. Collection of data on the publishers, editors, and telephone company directors and personnel involved systematic analyses of the Annual Assessments of Telegraph and Telephone Property in the State of Iowa, extant business records for 136 telephone companies, newspapers listed in $\mathrm{n} 3$ above, the archives of the Iowa Independent Telephone Association, the national trade magazine, Telephony, and the manuscript schedules of the 1915 lowa census.

The 1915 census listed the following major categories for the 945 persons identified in other sources as being connected with telephone companies: 616 $(65 \%)$ farmers, $73(7.7 \%)$ retired, $20(2.1 \%)$ merchants, $20(2.1 \%)$ carpenters, $17(1.7 \%)$ laborers, $8(0.8 \%)$ bankers, and $7(0.7 \%)$ lawyers. Only seventeen persons $(1.7 \%)$ identified themselves as telephone company employees.

11. Circulation figures for these newspapers are based on 'igures published in the papers themselves and Ayer's American Newspaper Annuals, 1900-1917.

12. The Washington Evening-Journal boosted its circulation from 1,157 


\section{Newspaper and Telephone Directorates}

Prior to Elder's editorship, Leigh Wallace owned the Evening Journal. A lumberman and elevator operator, Wallace also served as secretary to the Washington Telephone Company from 1909 to 1917. Together, Wallace and Elder held dominant managerial positions and decision-making powers for both the major newspaper and telephone operations in the county seat community of Washington for over twenty years.

The Washington Telephone Company was organized in 1897 as the commercial venture of two local businessmen. Within three years, the company was capitalized at $\$ 20,000$ and boasted 314 patrons. By 1907 the company was worth over $\$ 60,000$ and had 690 town phones, 222 farmer phones, and 13 toll phones. When Wallace joined the company as secretary in 1909 , it had grown to 840 town phones and 268 farm phones. By 1917 there were 1,366 town phones, 382 farm phones, 11 toll phones, and the company had assets of more than $\$ 200,000$.

As early at 1901, Elder had begun to promote the telephone in the pages of the Evening Journal. On December 24, 1901 he began a new section of the paper called "News by Telephone." The section continued for some time though the name was changed in 1903 to "Roundabout: Special Telephone and Rural Route News Service." Prior to 1907 there was little news about the telephone operations themselves. When Elder took over as president of the company, however, news stories and advertisements began to appear more regularly in his paper.

Throughout the spring of 1907, stories appeared about a proposed service connection between the Johnson County Telephone Company (whose secretary was the editor of the Daily lowa State Press) and about technical improvements in the system. At the same time Elder began an ad campaign aimed at attracting new telephone subscribers, especially farmers.

Any farmer who wants a phone on our lines, or any farmer lines wishing to connect with our system will do well to advise us, as early as possible, so we can order materials and get you fixed out as soon as weather will permit. . . . Line up and we will put up the line. ${ }^{13}$

in 1901 to 2,127 in 1917 . In the 1905 Iowa census, Washington County had a population of 20,116 . That figure dropped to 20,004 by 1917 . At the same time, the city of Washington's population increased from 4,255 to 4,544 .

13. Washington County Press, 1 March 1907. 
Elder also published ads prepared by the National Independent Telephone Association:

Are you on the social and business map? Is your name written on the pages of the Washington Telephone Company's Modern Exchange Directory? If you have no telephone, you have not lived the fullest life. The telephone is one of the seven great inventions of mankind. ${ }^{14}$

A vigorous advertising effort was made between 1912 and 1916 to counter an apparently serious challenge from a growing competitor: the Washington County Mutual Telephone Company, a farmer-organized line. By 1916 the mutual company was locked in a battle with Elder's company for subscribers and service. Elder and the secretary of the mutual company exchanged charges and countercharges about underhanded business dealings. ${ }^{15}$ In the end, the two companies were able to resolve their differences, but the mutual company was never able to penetrate significantly the town of Washington; Elder's company continued to lure farmers and farmer lines onto his system.

The degree of Elder's involvement with the telephone company appears to have been extensive. With his newspaper he promoted his telephone company, and from his telephone system he collected bits of news and gossip for his paper. And given his status as editor and president and principal stockholder, he was able to guide both enterprises along the paths of his own civic and economic interests.

Two editors connected with weekly papers in the southwestern Washington County town of Brighton also served as directors of local phone companies. G. W. Smith, publisher of the Brighton News from 1879 to 1904 or 1905, was also owner and manager of the Smith Telephone Company from 1900 to 1905. When Smith finally sold out to another local company, his line had a market value of $\$ 9,000$ and maintained over 300 telephones. During his tenure as company owner and manager, Smith maintained close supervision over the activities of the operations. He was also elected to the executive committee of the Interstate Independent Telephone Association in 1902.

14. Washington County Press, 26 January 1916.

15. Washington Evening Journal, 11 March 1916. 
Given the few extant copies of the News it was not possible to determine the extent to which Smith used his paper to promote the activities and interests of his telephone company.

The other Brighton newsman-telephoneman was Charles Bennett, who purchased the Brighton News in 1904 or 1905. In 1905 Bennett also went into a partnership to start the Cherryholmes Telephone Company located in the town of Crawfordsville. Bennett's connections with both the paper and the telephone company were very brief, however. The phone company filed with the state for only two years and then dropped from the public records, possibly having been absorbed by a larger company. And by 1906, the News had been sold again.

D. C. Miller, publisher and editor of the Kalona News for approximately the first thirty years of this century, was also the secretary for the Kalona Independent Mutual Telephone Company from 1911 to 1916. The Kalona Independent Mutual was one of two sister phone companies in the town. The independent mutual was made up exclusively of townspeople and never had more than eighty-five phones and no farm phones. Each patron on the system paid an annual fee of five dollars to maintain the lines and pay their portion of the switchboard costs. The independent mutual joined with about fifteen farmer mutual companies from the outlying areas to maintain the Kalona Switchboard Company.

Miller reported the developments in the phone company regularly, but no telephone advertisements appeared in his paper. His stories included reports on the addition of new farmer lines to the switchboard, company board of directors meetings, elections of company officers, operators' hours, and the construction of new lines or facilities. Because he served a mutual company, Miller had no extraordinary financial interests in the system and his position as secretary in the company did not afford him any special power or privilege.

One prominent Washington County man who had only minor affiliations with a county newspaper also had a role in a local telephone company. "Uncle Sam" Gardner was secretary of the Dutch Creek (Township) Telephone Company from 1905 to 1908 while he worked for the Washington County Press as a correspondent and columnist. Gardner, a retired farmer and Civil War veteran, was one of the elder citizens of the county 
and active in numerous community organizations. The Dutch Creek line he served was a small mutual farm line with fifteen to sixteen phones. Gardner appears to have had no special financial interests in the company and served as a director, as most mutual company members did, on a rotating basis.

T. T. Osborn owned and edited the largest circulation weekly in Iowa County, the Williamsburg Journal-Tribune. Between 1900 and 1917, Osborn edited the paper and served as the secretary of the Williamsburg Telephone Company, the largest independent commercial company in the county. Though not the county seat, Williamsburg became the largest town in Iowa County in part because of its rail and highway connections and its central location.

In 1900 Osborn and a local banker invested $\$ 4,000$ and began the phone system with 160 telephones. By 1917, there were 337 town phones and 423 farm phones on the line. Osborn was active in the company and served on the executive committee of the Interstate Independent Telephone Association in $1902 . .^{16}$

Osborn did not report or promote the activities of his company extensively in the Jounal-Tribune. He did engage in some saber rattling with the editor of the Iowa County Advertiser over politics and the county's telephone situation, however. The editor of the Advertiser, W. J. Naughton, had printed numerous attacks on Osborn's phone policies. Naughton was the secretary for the mutual phone company in the nearby town of Parnell. Being a staunch supporter of the mutual, non-commercial telephone cause, Naughton used his paper to blast the commercial lines like Osborn's Williamsburg system for robbing patrons and dealing unfairly with mutual lines. Eventually, Naughton and Osborn ironed out their differences on the interconnection between Williamsburg and Parnell, but they continued to take political shots at each other.

The editors and telephonemen in the town of Victor were less pugnacious and controversial. W. R. Prewitt was the editor of the Index, a Republican weekly established in 1872. In 1901 Prewitt served as secretary of the Victor-Hartwick Mutual Telephone Company, a small farm line with about eighteen phones

16. Telephony, 3 (May 1902). 
that connected with the town switchboard. The switchboard was mutually owned by about ten companies operating in and around the town. Prewitt made no mention of his company in the Index.

In 1903 Prewitt sold the Index to H. E. Powers who published the paper until 1907. During the same period, 1904 to 1909, Powers was secretary for the Victor-Ladora Independent Telephone Company. The Victor-Ladora line began in 1901 and had about twenty-six patrons at its peak. One interesting footnote to the end of Powers' involvement with the news-phone business is that when he sold the paper to G. B. Fullmer, the editor and publisher of the Victor Record, the Victor newspaper business continued to have connections to the telephone business. Fullmer's brother, Frank, was the secretary for the Southwest Telephone Company.

Both Prewitt and Powers seemed to have had little involvement with the telephone companies. They had little or no financial interest in the companies since they were mutuals. Their status as secretaries did put them into a policy-making position, but the mutual character of the companies precluded any special roles for them. Neither editor seems to have found his company particularly newsworthy or controversial, since coverage was minimal.

The only other person in Iowa County identified with both newspaper and telephone connections was also the only woman, Mary Kelly. The only mention of her tie between the two businesses was a small note published in the Marengo Republican on December 13, 1906:

Miss Mary Kelly has accepted a position with the Marengo Telephone Company and in consequence severed her connection as city local editress with this paper. Miss Kelly is an exceptionally fine news gatherer and we are sorry to lose her work on the Republican. May success attend her efforts wherever she may go. ${ }^{17}$

Apparently Kelly did not work for both media at the same time, and her role in the Marengo company is uncertain. The Marengo Telephone Company was a relatively large commercial line operating out of the Iowa county seat. Begun in 1902, the

17. Marengo Republican, 13 December 1906. 
Marengo line grew to have about 600 patrons. Kelly's name did not appear in any of the company records examined and was also absent from the 1915 Iowa census.

The Johnson County Telephone Company, one of three companies based in Iowa City, was a commercial venture started with a $\$ 25,000$ investment by two Wisconsin men. Within its first year of operation it attracted more than 300 subscribers throughout Johnson County. Samuel W. Mercer, an Iowa City banker and editor of the Daily Iowa State Press since 1895, was also a vice president of the Johnson County Telephone Company from 1906 to 1907. Apparently he played some role in forming company policy since he attended board meetings in both Iowa City and Wisconsin, but his precise role is unclear. The extent of his financial interests in the company also is uncertain. Since he was one of the wealthiest persons in Iowa City, his investment probably would have been substantial.

Mercer did use his editorial space in the Press to attack the "Bell Octopus" and its monopolistic practices.

The Bell Telephone monopoly got a good settling back in a decision of the United States circuit court at Boston on Wednesday. Its alleged patent on a transmitter was held to be not good. That is good news to all users of telephones. It lets a little water out of the Bell company's stock. ${ }^{18}$

He also served as a company apologist when the Johnson County line experienced trouble or breakdown. After one damaging storm, for example, Mercer pleaded,

Be Patient a Little While. The press expresses the hope that none of the patrons of the Johnson County line will waver in their support of the company. In the great misfortune that has come upon the line business friendship shown to it and to the brave hearted manager will be of the greatest value. . . . The Johnson County Company was the means of popularizing the telephone in this city and county.... Stand by the men who stood by you. ${ }^{19}$

The extent of Mercer's involvement with the Johnson

18. Daily lowa State Press, 2 March 1901.

19. Daily lowa State Press, 22 January 1904. 
County company appears to have been significant. Given his status in the company and his willingness to defend the company in his newspaper, Mercer had a strong commitment in the company, if not a financial interest in it.

Overall, the bond between these interlocking newspaper and telephone company directorates was firm. The relatively high status of these directors in the news and telephone businesses, their apparently significant financial commitment to these media, and their frequent use of one medium to promote the other suggest a significant degree of involvement of newspersons with the establishment, maintenance, and direction of telephone companies in southeastern Iowa.

Without exception, the newspaper editors and publishers held positions as telephone company officers: presidents, vicepresidents, and secretaries. Generally, this seems to indicate that their involvement was at the level of policy-making and system management. The specific power attached to these positions divided roughly along the lines between commercial and mutual companies. Directors in the commercial telephone companies seemed to have had great power and freedom to make personal decisions and to implement them. Directors of mutual companies shared power on an equal basis with all members of the organizations, and hence had less power, relatively speaking, than their commercial counterparts. With the possible exception of G. W. Smith of the Smith Telephone Company in Washington County, none of the editors had close relationships with the daily operations of the telephone companies.

Not surprisingly, the three largest telephone companies in the three counties were commercial operations. The principal directors of these companies edited or published the three largest daily and weekly newspapers in their respective counties. They also were in the top fifteen percent income bracket for telephone personnel reporting 1914 income.

Editors' and publishers' direct financial investment in the companies, also divided along commercial and mutual lines. The directors in the commercial companies had a significant commitment financially to their companies. Mutual companies, by definition, spread the financial base to all their members, so 
no one person had a greater financial commitment than another. Those with substantial financial investments in a compar'r would be expected to take a more active role in the compar: 'r promotion and defense.

Indeed, those publishers and editors who had a substantial fin ancial investment in a telephone company were the most " $v$ ' : al" about reporting, promoting, and defending their companies. Newspersons who were associated with mutual companies would often devote significant space in the newspapers for routine company activities or for attacking what they took to be unethical business practices among their commercial counterparts. In no case, however, did advertisements appear for mutual telephone companies. Advertisements appeared for commercial companies in papers that were affiliated with those commercial operations or in towns that were served only by a ccrmmercial company.

Nearly every newsperson, regardless of commercial or mutual company affiliation, provided some news coverage of the developments taking place relative to their companies. Those affiliated with the commercial companies no doubt had both editorial and financial motivations for their coverage of their phone systems. For those associated with mutual companies, both editorial and philosophical motivations accounted for the coverage they provided.

The promotion of the telephone companies by these newspapers resulted in a two-fold benefit. First, the editors and publishers gained financially from the increased use of the phone. In addition to the commercial companies making a direct profit from their patrons, they also made money by permitting local businesses to advertise over their lines for a fee. The newspersons involved with the commercial companies were thus able to take advantage of the billings for both the print and the new electronic media. For both the commercially and mutually affiliated newspersons, the increased use of the telephone promised to increase their profitability, if only indirectly, by encouraging centralization and greater dependency on the towns of which they were a part.

And the greater use of the phone by local residents meant increased newsgathering capabilities for the papers. As one weekly editor on a mutual system put it: "Call us up and report 
every piece of local news you can think of. We don't want to miss a word of the real local news of this neighborhood. The people have now a better chance than ever before to help us along this line." ${ }^{20}$ As early as 1906 evening papers affiliated with mutual exchanges attempted to establish a statewide independent telephone press association based in Des Moines. ${ }^{21}$ Thus, these newspersons were keenly aware of the informational and financial benefits to be derived from the successful dissemination of the telephone and measured the extent of their coverage and promotion of their telephone companies accordingly.

Newspaper owners, editors, and publishers played a pivotal role in the development of the independent telephone business in southeastern Iowa, a role that went well beyond the employment of the telephone for newsgathering purposes. As directors in these companies, they helped to establish and maintain both the commercial and mutual wings of the independent telephone movement. Financially, philosophically, and editorially they helped to promote the telephone as an end in itself, and as an aid to their news operations. A close relationship between the newsroom and the telephone office thus extends as far back as the establishment of the telephone industry.

20. Wellman Advance, 27 June 1901.

21. lowa City Citizen, 21 March 1906: "The independent telephone companies of lowa have decided to establish a press association for the evening papers of the state whom they will supply with a press report daily. The move is a new one on the part of the mutual exchanges but it is believed by newspapermen that the venture will prove a profitable one and a satisfactory one. The news of the state is to be gathered by the toll offices all over Iowa and sent into the mutual clearinghouse in Des Moines. At that point it will be edited and sent out over the state to the patrons of the association. The local mutual company, being one of the companies involved, will act as one of the news centers of the association." 
Copyright of Annals of Iowa is the property of State of Iowa, by \& through the State Historical Society of Iowa and its content may not be copied or emailed to multiple sites or posted to a listserv without the copyright holder's express written permission. However, users may print, download, or email articles for individual use. 